\title{
Reframing Medieval Anatolia, Caucasia, and the Aegean: Narratives, States, and Cities
}

\section{Matthew Kinloch*}

There is no single totalising modern historiographical narrative for thirteenth- and fourteenth-century Anatolia, Caucasia, and the Aegean. The modern narration of this past is constituted by a collage of narratives, each of which is centred on specific state projects. This article sketches the limitations of the statist common sense that has framed the modern narration of this period, with specific reference to the two most prominent narratives, the decline of Byzantium and the rise of the Ottomans. It then outlines in broad terms the heuristic potential in replacing the state with the city as the foundational unit of analysis for the study of medieval Anatolia, Caucasia, and the Aegean. This approach is intended to build on the theoretical groundwork laid by the pioneers of a holistic medieval Anatolian studies and the increasing number and quality of studies centred on urban centres. The study finishes with a case study, examining the manner in which the failed siege of Attaleia/Antalya/Satalia in 1206 and the successful conquest of the city in 1207 have been integrated into and made meaningful within state-centric reconstructions of the history of the early thirteenth century. In particular, it demonstrates how the centring of these states emphasises elite male characters and obscures the roles played by the city's population. This article is intended to set out a broad framework for the other, more fine-grained contributions to this thematic section.

Keywords: Medieval history; states; narrative; historiography; cities; Anatolia; Caucasia; the Aegean

According to the classicizing Greek history of Niketas Choniates, Ghiyāth al-Dīn Kaykhusraw I (r. 1192-1196, 1205-1211), the ruler of the Seljuq sultanate of Rum, besieged the city of Attaleia/Antalya/Satalia on the southwestern coast of Anatolia for sixteen days in 1206. ${ }^{1}$ However, a coalition formed between the city's population and a contingent of Latins from Cyprus, summoned to the defence of the city by its ruler, Aldebrandinos, and other urban elites forced the Seljuqs to withdraw. Although Choniates' narrative does not describe the

* Correspondence details: University of Oslo, Postboks 1020 Blindern 0315 Oslo, matthew.kinloch@ifikk.uio.no This article is part of the themed section Urban Agencies: Reframing Anatolian and Caucasian Cities (13th-14th Centuries), guest editors: Bruno De Nicola and Matthew Kinloch. To read all related articles, please access: dx.doi. org/10.1553/medievalworlds_no14_2021.

1 Niketas Choniates, History, ed. van Dieten, 639, trans. Magoulias, 351. The city is named and transliterated into English differently in Greek, Persian, Arabic, Syriac, and Latin, see below, p. 15. 
subsequent fate of the city, the Seljuq historian Ibn Bïbì, the Arab historian Ibn al-Athìr, and the Syriac historian Gregory Bar Hebraeus all report that in 1207 Kaykhusraw's forces returned and captured it. While Ibn Bïbì narrates in detail a quasi-epic siege in which the Seljuqs overcame the Frankish defenders, Ibn al-Athir and Bar Hebraeus narrate how the Greek-Latin coalition collapsed and the local populace allied with the Seljuqs against their erstwhile allies. ${ }^{2}$

The conflicts around Attaleia/Antalya/Satalia in 1206 and 1207- which will be explored as a case study in the final section of this article - exemplify how the events of the thirteenthand fourteenth-century Anatolian, Caucasian, and Aegean past have been narrativized and made meaningful in modern historiographies. Although modern historiographical and disciplinary traditions - most notably from Byzantine, Seljuq, and crusader studies - have framed these events in different ways, all display a similar logic, incorporating the city's capture into statist narratives and using the rulers of these states (and opposing factions) to supply meaning to events.

This article identifies and explicates the centrality of statist narratives in the modern narration of the thirteenth- and fourteenth-century Anatolian, Caucasian, and Aegean past and both the limitations and predispositions that derive from the state's hegemonic position. It then proposes urban centres and the agencies of their populations as both an alternative unit of analysis and also an alternative framework for structuring macro-historiographical narratives of the thirteenth- and fourteenth-century Anatolian, Caucasian, and Aegean past with reference to the events of 1206 and 1207.

\section{Statist Narratives}

There is no single modern historiographical narrative for thirteenth- and fourteenth-century Anatolia, Caucasia, and the Aegean. The broadest modern historiographical narratives that claim this space and period as their object of description and explanation are centred on specific state projects. ${ }^{3}$ Whether produced explicitly as a state or more often - given pre-modernists' reticence to claim statehood for their objects of study - an empire, a sultanate, a kingdom, a principality, a beylik, or a city-state, some polity almost always frames the modern narration of this past. Consequently for modern scholars, the thirteenth- and fourteenth-century Anatolian, Caucasian, and Aegean past is principally constituted of a collage of state-centred narratives. The stories of the decline and fall of the Byzantine - i.e., medieval eastern Roman - empire and the rise of the Ottomans are dominant, but they are accompanied by sub-hegemonic - predominantly national and ethno-nationalist - narratives, such as those of the Armenian Bagratuni, the Georgian Bagrationi, the Latin empire of Constantinople and its feudatories, the Seljuq sultanate of Rum, the second Bulgarian empire, and the Genoese and Venetian maritime empires.

Ibn Bībī, Al-Awāmir al-'alā'iyyah, trans. Duda, 44-46; Ibn al-Athïr, Al-Kāmil fĩ al-tärìkh, 12, ed. Tornberg, 252-253, trans. Richards, 123; Bar Hebraeus, Makhtbhanuth Zabhne, trans. Budge, 420-421.

3 Three influential examples from Byzantine studies illustrate both this centring of the state and the varied forms it takes when history is produced as military-political narratives or as economic or social history. Shepard, Cambridge History of the Byzantine Empire, Laiou, Economic History of Byzantium, Haldon, Social History of Byzantium. This centring of the state (or rather multiple states) can even be seen in studies that transcend the limits of a single discipline/state project. For example, Vryonis, Decline; Cahen, Pre-Ottoman Turkey; Korobeinikov, Byzantium and the Turks. 
The state provides a foundational common-sense framework for the disciplines from which these historiographical narratives emerge. The entire field of Byzantine history, for example, is dominated by and largely synonymous with the story of the Roman state in the medieval period. The narrative of Rome's decline and fall - which, thanks in part to Edward Gibbon's eighteenth-century intervention, remains the dominant story of Byzantine historiography - is the story of a state. ${ }^{4}$ Its emperors are judged to be sgood ‘ or sbad ‘ depending on the extent to which they enable the state to reproduce itself, especially on an expanded scale, while vast periods of the past are labelled as >dark ages` or >renaissances`, depending on the territorial extent of the state. Even those framings which push the Byzantine world beyond the territorial confines of the empire maintain a statist framework. In practice, for example, Dimitri Obolensky's conceptualisation of the Byzantine world as a commonwealth, in part, ends up projecting the spectre of the Roman state beyond its territorial limits. ${ }^{5}$

The collapse of the Roman state, following the conquest of Constantinople by the forces of the fourth crusade in 1204 and the subsequent disintegration of the empire, interrupts the traditional state-centric structure typical of the narration of Byzantine historiography. This interruption, however, demonstrates the synonymity of the narrative of the Byzantine state and the discipline of Byzantine history, since not even the collapse and consequent absence of the structuring imperial state has displaced the state-centric logic that governs modern Byzantine historiography. This logic is maintained in two principal ways in the narratives that have emerged to construct the post-1204 Byzantine world. First, this new world is framed in terms of interstate anarchy, in which states are produced as competitors for dominance in a zero-sum game. This language, which is regularly deployed commonsensically, presumes the tenets of modern realist international relations theory and realpolitik, without explicitly engaging with the theoretical apparatus of this scholarly tradition. ${ }^{6}$ The Byzantine empire is described as fragmenting into a number of successor states. This phrasing, which has become a trope, offers the dominant metaphorical framing of the history of the period. The states that emerged in the former territories of the empire - some formed by the Latins that had sacked the city and others created by Roman elites - and the pre-existing states, such as the Seljuq sultanate and second Bulgarian empire, that expanded into the vacuum it left behind are produced as fragments of and successors to the given hegemonic state for Byzantine studies. In the case of non-Roman polities this framing depends on an implicit assumption of a classical and early medieval Roman empire that held all Anatolia. The story of thirteenth-century Byzantine history, is consequently a narrative of interstate competition between these states for hegemony over the former territories of the twelfth-century Byzantine empire. ${ }^{7}$ Second, one of those competitors is privileged as the natural hegemonic state

Gibbon, Decline and Fall; Bryer, Gibbon and the later Byzantine Empires, 101-16.

5 Obolensky, Byzantine Commonwealth. For this phenomenon as articulated in Caucasia and specifically Armenia, see Rapp, Caucasia and the First Byzantine Commonwealth; idem, Caucasia and the Second Byzantine Commonwealth.

6 The only extended study by an international relations theorist on Byzantine history has not, in general, been either well received or particularly influential, Luttwak, Grand Strategy. For explicit and consistent relevant use of realpolitik, see Dadoyan, Armenian Realpolitik in the Islamic World.

7 The various competitors are typically understood as successor states, that is as successors to the east Roman state, regardless of their relationship to the pre-1204 Roman empire. 
for this space throughout, since the so-called empire of Nicaea is systematically privileged and treated consistently as if it were, from the moment of Constantinople's conquest in 1204, already the Byzantine empire itself in exile, despite the power and pretentions of its various rrivals‘. The story of thirteenth-century Byzantine history has become the story of the reconstitution of the Byzantine empire as a hegemonic state along the lines of the twelfth-century empire. ${ }^{8}$

States are centred in the narration of thirteenth-century Byzantium, both by framing the period in terms of the competition between states and by naturalising Nicaean hegemony at the heart of the dominant narrative and in all possible counter-narratives. Critiques of Nicaea's privileged treatment have simply offered up alternative statist narratives based on one of its scompetitors s. Narratives arguing for the legitimacy and importance of the empire of Thessalonike/despotate of Epirus, the empire of Trebizond, or even the Latin empire of Constantinople have been offered in contrast to the Nicaean narrative, but they are underpinned by the same logic. ${ }^{9}$ This is not the place to unpick the inconsistencies of the logic that has produced this specific narrative, which rests upon the teleology of Constantinople's socalled rreconquest in 1261 by the forces of Nicaea. ${ }^{10}$ It is sufficient here simply to highlight the statist logic and narrative framework that underpins historiographical narration in the domain of Byzantine history.

The traditional narrative of the rise - as well as, for that matter, the fall - of the Ottoman empire is underpinned by the same state-centric logic and emerges from a discipline that is similarly aligned with a single imperial project. Just like their Byzantine counterparts, Ottoman sultans are evaluated according to their success in enabling the state to reproduce itself and expand its territorial holdings. The period immediately preceding the emergence of the Ottoman empire in the thirteenth and fourteenth centuries has traditionally been reconstructed according to a similar logic as that of the collapse of the Byzantine state in the thirteenth century. The pre-Ottoman world (functionally Anatolia) has traditionally been framed as a ferment of states each competing to occupy the naturalised role of regional hegemonic power - itself partially framed by the logic of Byzantine imperial history. The history of fourteenth-century Anatolia, written from this perspective, is the history of the competing Anatolian beyliks, into which the Constantinopolitan Palaiologan/Byzantine empire and the empire of Trebizond (the Byzantine beylik) are incorporated as potential competitors. At the same time, a single state project, the Ottoman state, is teleologically singled out and privileged as the natural hegemonic state for the region. ${ }^{11}$ Within this framework, the Seljuq sultanate of Rum has been produced as one of a string of rauthentic ' Turkish states to which both

8 Kinloch, Rethinking Thirteenth-Century Byzantine Historiography, 40-68; idem, The Nikaian Narrative, 471-490.

9 For examples in the case of the empires of Trebizond and Thessalonike, see Eastmond, Art and Identity; Karpozilos, Ecclesiastical Controversy.

10 For a critique of this logic see Kinloch, Rethinking Thirteenth-Century Byzantine Historiography, 40-68.

11 This concept and logic also travels to Byzantine studies, where the Ottoman empire is tacitly understood as the natural successor to Byzantium, since the space occupied by both states has been naturalised as a space that should be occupied by a single state. The logic of the Byzantine state thus survives 1453 not only as the spectral (and yet somehow unitary) Byzance après Byzance, but also in the way we talk about the Ottoman empire as a natural organisational unit for the space that the Byzantine state once inhabited. For which see, Laiou, Byzantium and the neighbouring powers, 49. 
the Ottoman empire and modern Turkish nation-state are the natural heirs. At the same time, the period of Mongol domination in Anatolia was produced until recently as "an unwelcome interlude that wrecked the country and left no formative traces «. ${ }^{12}$ This historiographical tradition and the framing of thirteenth- and fourteenth-century Anatolian history as pre-Ottoman have been systematically critiqued in the course of the twenty-first century, although the centrality of the Ottoman and other states has largely remained. ${ }^{13}$

As the symbiotic stories of Byzantine decline and the rise of the Ottomans make apparent, statist narratives are not discrete entities, but come into being already jumbled together. ${ }^{14}$ Alongside the rise of the Ottomans, the story of Byzantine decline, for example, also overlaps with that of the steady expansion of Italian city-states into the eastern Mediterranean - itself a fraction of the story of the rise of the capitalist West, made manifest in the conquest of Constantinople in 1204 by the forces of the fourth crusade. The often explicitly ethno-nationalist narrative of the birth of the second Bulgarian empire, also at the cusp of the thirteenth century, similarly intersects with the story of Byzantine decline, albeit framed in terms of secession and internal collapse, rather than foreign incursion. ${ }^{15}$

Acknowledging that modern historiography concerning this period and space is dominated by statist narratives is not to say that these narrative traditions produce all events in the same way. Patently, the same events are presented in dramatically different ways depending on the statist narrative that informs their production. The Latin conquest of Constantinople in 1204, the Mongol victory at Kösedağ in 1243, and the Ottoman conquest of Constantinople in 1453, are inflected differently by the modern scholars who have come to identify with the hegemonic state of their period, space, or discipline, whether Byzantine, crusader, Mongol, Seljuq, or Ottoman. However, regardless of the variety of meanings imposed on these events by specific modern narratives and historiographical traditions, they are all made meaningful according to the same state-centric logic, which produces moments of the past as either 'good` or ১bad` for specific state projects. The Seljuq defeat by the Mongols at the so-called battle of Kösedağ (1243) offers an interesting illustration of this logic at play in multiple ways. While defeat at Kösedağ is framed as a cataclysmic and transformative moment for the Seljuq sultanate, symbolizing the end of a sgolden age of Seljuq authority, it is accorded less transformative power in Mongol historiography, where it is produced as one of many major victories. ${ }^{16}$ At the same time, this battle and the wider impact of the Mongols on the Aegean

12 Melville, Anatolia under the Mongols, 51.

13 Peacock et al., Introduction. For a critique of this tradition framed as medieval Anatolian studies, see below, p. 13 .

14 For this symbiosis see Paul Linder's justification for periodisation in the Cambridge History of Turkey: Byzantium to Turkey (1071-1453). Lindner, Anatolia, 1300-1451, 102, "This chapter narrates and discusses some major lines of development in Anatolia between the turn of the fourteenth century and the second accession to power of Mehmed II. The emphasis lies on the early Ottoman enterprise, thanks to the fact that it had become the major power in the peninsula by the end of the 150 years under discussion. The end point of our coverage is entirely reasonable, as there is general agreement that Mehmed the Conqueror's reign was a turning point in the creation of one imperial polity and the wreck of another, Byzantium."

15 For a recent overview of the historiography of the second Bulgarian empire see, Madgearu, The Asanids, 11-28.

16 For the contrast in treatment compare the following, Cahen, Pre-Ottoman Turkey, 137-138; Jackson, Mongols and the West, 74 . 
world has generally been framed in terms of its impact on various state projects. In the case of the Byzantine world, Kösedağ has been depicted as producing a moment of respite from Seljuq territorial westward expansion that allowed the empire of Nicaea to form and expand. ${ }^{17}$ Regardless of the varied ways that this event has been narrativized and made meaningful in modern historiography, that meaning has generally been the outcome of a statist narrative logic.

The stories of Byzantine decline and the rise of the Ottomans are perhaps the most paradigmatic examples, but narratives centred on specific states that offer similar structures and logics are ubiquitous. Modern historiography of the Caucasus in this period, for example, is dominated by the story of the rise and fall of the Bagratid Georgian kingdom - which reached the zenith of its so-called 'golden age at the end of twelfth century, before rapidly receding in the face of Khwarezmian and then Mongol pressure in the early thirteenth century. ${ }^{18}$ The story of the Cilician principality/kingdom of Armenia offers a similar schema and logic: from its emergence at the end of the eleventh century and its consolidation of power - exemplified by Lewon I's coronation as king - at the end of the twelfth century, to its subordination to the Mongol Ilkhanate in the thirteenth century and collapse under the Lusignians in the fourteenth. ${ }^{19}$

In short, the dominant macroscopic modern historiographical narratives concerning thirteenth- and fourteenth-century Anatolia, Caucasia, and the Aegean centre the state in two foundational ways: first, by focusing on specific state projects and, second, by situating those projects within a wider narrative of interstate competition. These historiographical narratives both directly construct the past as history and frame the past's modern production through its material traces. Not only does this produce the state as the natural unit of analysis, but it also brings with it a host of predispositions.

Statist narratives in modern historiographies about the medieval world are the product of the state's hegemony over its subjects (i.e., the majority of humanity) both in the past and today. Both the source material for modern narratives and those narratives themselves reflect a statist common sense that has become naturalised as past reality. ${ }^{20}$ These narratives are stories of, by, and for the ruling class and reflect that class's hegemony in particular times and places that aggregate into a historical vision reflecting the successive world-views of dominant elites. Consequently, these narratives justify the hierarchy and exploitation on which the state and its concomitant elites depend, not least, by producing states as natural entities for the organisation of human societies and thus as natural units of historical analysis. The naturalisation of class violence and oppression, fundamental to these narratives, are intertwined with the story of gender violence and patriarchy, a development for the most part historically coeval with statehood, since control of the means of reproduction has proved essential to the maintenance of the division of labour and state power at the most fundamental level. ${ }^{21}$

17 Generally, see Giebfried, Mongol invasions and the Aegean, 129-139; Morgan, Mongols and the Eastern Mediterranean, 198-211; May, Mongol presence, 133-156. On Nicaea in particular, see Langdon, Byzantino-Mongolica, 95-140.

18 For example, see Rayfield, Edge of Empires, esp. 98-117.

19 The emergence of this Armenian state has been understood as the end of what Seta Dadoyan has called the >Armenian Intermezzor. Dadoyan, Armenian Realpolitik in the Islamic World, 7-9.

20 For the concept of hegemony, see Gramsci, Prison Notebooks; Laclau and Mouffe, Hegemony and Socialist Strategy, esp. 7-46.

21 For an early articulation of this, see Lerner, The Creation of Patriarchy. 
The confluence of class and gender violence in modern historiographical narratives can be seen most clearly in the manner in which male rulers have become naturalised as the protagonists of traditional historiographical narratives. The decision making and personality of emperors, sultans, and kings occupy a pre-eminent position in the description and explanation of the thirteenth- and fourteenth-century past. Despite the critical reappraisal of a historiography dominated by the imperial palace, explicit biographical approaches are retained and the protagonists of modern historiographical narratives concerning this period are most often the male rulers of states, who personify the state, representing it in narration in various combinations of metaphor, metonymy, and synecdoche. ${ }^{22}$ This is a foundational problem created by textual survival, which is not sufficiently dealt with by simply acknowledging the bias of source material, if the same interpretive models are retained.

At the same time, the dominance of states exacerbates the tendency for historiographical narratives to be co-opted by modern ethno-nationalist state projects. The historic and contemporary impact of various southeastern European, Anatolian, and Caucasian statist ethno-nationalisms, have been well studied. However, it is worth acknowledging that these discourses generally depend on the identification of a modern with a medieval nation-state. Even conversations concerning Byzantium that have sought to detach Byzantine identification from specific nation-states, by stressing Romanness as an organizing identity, have fundamentally served to produce an ethno-nationalist narrative as if there were a modern Byzantine/Roman state. ${ }^{23}$

\section{Cities and Urban Agencies}

The state-centric framework provided by traditional historiographical narratives produces a statist vision of the past, which not only reflects but also compounds the overrepresentation of the state and the male elites, who monopolised the hegemony it established, both in the past and over the textual record. The remainder of this article will suggest that cities, and the agencies of their populations, offer an alternative organising unit of analysis to the state. The aim here is twofold, not only to denaturalise the monopoly held by the state in the domain of modern historiographical narration, but also to sketch one potential framework for a macroscopic historiography of thirteenth- and fourteenth-century Anatolia, Caucasia, and the Aegean, capable of sustaining comparative analysis and military-political narration without resorting to traditional statist narratives and logics.

It is worth pointing out at this stage, however, that this article's objective is not to propose the correct way of narrating the past by replacing statist historiography, but rather to suggest an alternative heuristic and analytic focus (understood to be one of many). It begins with the assumption that modern historiography is just that, modern, and that the narrative frameworks through which it produces the past are substantive constructions rather than transparent representations of past reality. By decentring the state, a critical reanalysis of this period and space organised around cities and their populations has the potential to produce a less elitist, hierarchical, male, and ethno-nationalist historiography. This is not so much because of any immanent liberatory qualities of cities, but rather because they offer a suitably ubiquitous, well-studied, and well-sourced unit of analysis for the organisation of alternative narratives, capable of challenging state-centric historiography. 
Urban centres constitute a common feature of Anatolia, the Caucasus, and the Aegean during the period under discussion, although one that was neither uniform nor equally distributed. Throughout most of Anatolia, the Caucasus, and the Aegean, there were large and more often medium-sized settlements, where populations of humans concentrated. This is not to say that cities were the only important constitutive elements of this world - indeed, as Philipp Niewöhner has noted, middle- and late-Byzantine Anatolia »should probably be conceptualized as a predominantly rural society ${ }^{24}{ }^{24}$ However, the ubiquity of urban settlements and the regularity with which they appear in the surviving textual record offers the potential to ground a non-statist historiography, in a way that the textual footprint of rural populations rarely allows.

When integrated into the military-political history of Byzantium dominated by the state, its male ruling elite, and military-political affairs, cities have tended to be produced in ways that subordinate their stories to the state. ${ }^{25}$ Deurbanisation in the so-called Dark Ages, for example, is produced as an expression of the decline of the state. Cities tend to become most prominent when they are made synonymous with the state. Such cities as Constantinople and Konya became defined by their role as the central hub of a particular state. Indeed, several states have come to be known in scientific literature by reference to their metropolitan centres, from the empires of Nicaea and Trebizond, to Erzincan, which has given its name to both the Armenian principality and the Turkoman beylik that were centred on the city in the thirteenth and fourteenth centuries. ${ }^{26}$ Cities appear in military-political narratives of state expansion and collapse as sites and objects of action (i.e., places that are conquered or to which rulers travel), but less often as agents in their own right. ${ }^{27}$ Even if cities are not produced as an expression of the state's success or fully assimilated into it as metonymic centres, cities and the autonomous actions of their inhabitants are defined either in opposition to it, in terms of rebellion against or resistance to some state or ruler, or as proto-states, as the case of Attaleia/Antalya/Satalia addressed below will illustrate.

To date, the most sophisticated and successful critical reframing of the statist historiographical traditions that have dominated the historiography of thirteenth- and fourteenthcentury Anatolia, Caucasia, and the Aegean has come in the form of medieval Anatolian studies. Scholars, such as Sara Nur Ylldı and Andrew Peacock, have offered the framing of medieval Anatolian studies in opposition to the traditional teleological, nationalist, and anachronistic framing of pre-Ottoman (or even medieval/Seljuq) Turkey ${ }^{28}$ This reframing has been dominated by scholars working on the Seljuq sultanate of Rum and Mongol Anatolia, albeit in collaboration with scholars working on Cilician and Greater Armenia and Byzantium. ${ }^{29}$

24 Niewöhner, Urbanism, 59.

25 In part, this seems to be because the explicit study of cities has principally fallen to archaeologists, specialists in material culture, or social and economic historians.

26 In the cases of Nicaea and Trebizond, urban signifiers are paired with dynastic identifiers and used interchangeably with the Laskarid empire and the empire of the Grand Komnenoi.

27 Agency is understood here in the broadest possible sense as the manifestation of the capacity to act. Without precipitating a debate concerning the terminology and the metaphysics of intentionality, agency is deployed to signal a clear focus on who or what is able to act in both medieval and modern narratives concerning the period. Highlighting agency is intended to redistribute some capacities from the state and its ruler to other actors.

28 Peacock and Yıldız, Introduction, esp. 6-12.

29 E.g., Peacock and Yildı, The Seljuks of Anatolia. 
This critical reframing has principally served to limit the influence of the Ottoman empire on the study of the period before it existed and to challenge the ethno-nationalist logic that informed its narration. While it has not entirely dislodged the Seljuq sultanate of Rum from its position as the given hegemonic state for the study of Anatolia in this period, it has denaturalised its framing as one of a string of rauthentic pre-modern Turkish states and provided a more inclusive framework for the incorporation of other histories, whether Turkoman, Mongol, Armenian, or Byzantine. ${ }^{30}$

Shifting the framework of analysis to the macro-level of Anatolian studies has revealed a number of potentials that can be developed, particularly its success in embedding the story of individual states in a wider context given by the geographic framing of Anatolia. Of course, as the proponents of medieval Anatolian studies have noted, and have sought to offset, semigeographical terms, such as Anatolia, Caucasia, and the Aegean, cannot stand entirely outside traditional statist narrative paradigms. Geographical space cannot be taken as either absolute or a natural given, and certainly cannot be uncritically used to replace state-centric frameworks, not least because of the association of the term Anatolia with Kemalist Turkish state-nationalism. ${ }^{31}$ The area that has recently been framed by scholars working on the sixteenth century as the Ottoman east (i.e., northern Kurdistan/western Armenia/eastern Turkey) cannot really be identified geographically outside of the claims of specific states and ethno-nationalisms to the territory. ${ }^{32}$

Macro-geographical framings have in part managed to escape individual statist narrative frameworks by embedding them into frameworks of interstate politics and (inevitably) competition across larger geographical regions. Revisionist accounts of the potential of the Trapezuntine and Epirot states in the thirteenth century or of various beyliks in the fourteenth as opposed, respectively, to Nicaean- and Ottoman-centric teleology, retain the state and interstate competition as their organisational framework. Likewise accounts of the fourteenth century that produce Anatolia and Caucasia as outlying provinces of the Ilkhanate, despite successfully shifting the scale of analysis - to include a story of the vast Mongol empires that spanned Eurasia and their rivals, such as the Egyptian Mamluk sultanate - maintain the centrality of states.

The simple contention of this article and the workshop from which the papers in this section of the volume arose, is that there is heuristic potential in replacing the state with the city as the foundational unit of analysis for the kind of macroscopic and open historiography pioneered by the Anatolian studies practitioners. Instead of aggregating the stories of states and their conflicts into a macro-historical framework, why can the city not serve this function? Recent scholarship has seen an explosion of increasingly detailed and powerful studies of specific urban contexts. ${ }^{33}$ Such studies offer promising foundations for a granular and open synthetic historiography of medieval Anatolia, Caucasia, and the Aegean.

30 Even studies that are not explicitly produced within this tradition offer a vision of it. See for example, Eastmond, Tamta's World.

31 The Russian imperialist undertones of terms such as Transcaucasia and Ciscaucasia offer a similar problem. Generally on space as relational, relative, and absolute, see Harvey, Spaces of Global Capitalism, 119-148.

32 For an astute treatment of this problem in the study of the nineteenth century, see Sipahi, et al., Ottoman Historiography's Black Hole, 1-15.

33 For illustrative examples, see Redford, Landscape and the State; idem, Legends of Authority; Asp, Trebizond and Constantinople; De Nicola, The Chobanids of Kastamonu. For a broad overview and a variety of archaeological case studies, see Niewöhner, The Archaeology of Byzantine Anatolia. 


\section{Attaleia/Antalya/Satalia (1206/1207)}

The manner in which the failed siege of Attaleia/Antalya/Satalia in 1206 and the successful conquest of the city in 1207 have been integrated into and made meaningful within modern reconstructions of the history of the early thirteenth century offers an illustrative example of how relatively typical textual material has been incorporated into traditional statist narrative frameworks. In particular, it demonstrates the point that these frameworks emphasise elite male characters and obscure the role of the city's population.

As in the study of various localities, the study of Attaleia/Antalya/Satalia's turbulent history in the early thirteenth century has been recently advanced by the work of Scott Redford and Gary Leiser, whose study of the fatihnäma (fetihnāme) inscriptions, commemorating the later Seljuq conquest of the city in 1216 , provides a foundation for the sort of conceptual prognostication undertaken here. ${ }^{34}$ In their examination of events of 1206 and 1207, understood as preamble and context for their study of the 1216 fatihnäma, they have set out a firm chronology of events and identified all the relevant source material. Building on previous scholarship from various disciplines, the basic narrative that Redford and Leiser have pieced together from passages in narratives in various languages and traditions, as well as from the fatihnama, is as follows. ${ }^{35}$ In 1206 a Seljuq siege of the city failed thanks to military support from the Latin kingdom of Cyprus. A second Seljuq siege in 1207 was, on the contrary, successful thanks to dissension between the city's inhabitants and the Cypriots. Although Redford and Leiser's treatment offers a synthesis of various schools of thought, the narrativization of these events in modern scholarship has tended to take three distinct forms, depending on whether the Byzantine, Seljuq, or Cypriot/Crusader states have been centred. Each of these traditions produce everything from the name of the city to the meaning of events differently. However, they each do so according to the same statist logic.

At the most foundational level, each of these three historiographical traditions deploy different signifiers to identify the city itself - Attaleia (Byzantine), Antalya (Seljuq), and Satalia (Cypriot/Crusader) - necessitating the cumbersome triple naming of the city throughout this article. ${ }^{36}$ These differences in linguistic and transliterative preferences extend to the names of characters as well, with Greek, Persian/Turkish, and Latin versions of names making the searching of indexes laborious work. ${ }^{37}$ Beyond naming practices, however, each tradition is also organised around a different principal protagonist, in each case the male ruler of the privileged state or, in the case of Attaleia, city(-state). The Byzantine story is dominated by the mysterious figure of Aldebrandinos - according to the History of Niketas Choniates, "an

34 Redford and Leiser, Victory Inscribed, 89-91. These events are generally treated together with the events of 1212 , in which the city's inhabitants once again enlisted Cypriot aid against the Seljuks, and of 1216, when the city was again conquered by the Seljuks.

35 For example, see Hellenkemper and Hild, Lykien und Pamphylien, 297-341, esp. 308.

36 In fact, it is worth noting that Antalya is repeatedly mistaken for Antakya in the source material. For a more detailed list of the various terms used to identify the city, see Hellenkemper and Hild, Lykien und Pamphylien, 297.

37 On his first mention, for example, Redford and Leiser simultaneously use all the various options for the name of »Aldobrandino/i/us«; Redford and Leiser, Victory Inscribed, 90. 
Italian by birth who was strictly raised according to Roman traditions « and had become ruler of the city in the early thirteenth century. ${ }^{38}$ Modern Seljuq histories, in contrast, are dominated by the sultan Ghiyāth al-Din Kaykhusraw I (r. 1192-1196, 1205-1211), while histories focused on the Kingdom of Cyprus and the crusader states revolve around the person of Gautier de Montbéliard, the regent of the Kingdom of Cyprus (1205-1210) ${ }^{39}$

Beyond naming and the central characters, each tradition makes these events meaningful by incorporating them into different statist narratives. For Byzantinists, it is one of many examples of regional disintegration and separatism that started after the death of Basil II in 1180 and intensified after the Latin conquest of Constantinople in $1204 .{ }^{40}$ As such it is contextualised alongside the srebellions twelfth-century Cyprus and Bulgaria to thirteenth-century Philadelphia, Trebizond, and the Maeander valley. For historians of the Seljuq sultanate of Rum it is a key conquest in the expansion of the Seljuq state, which along with the capture of Sinope represents a symbolic moment of expansion. ${ }^{41}$ Historians of Cyprus and the crusader states, by contrast, have made these events meaningful through the story of the kingdom of Cyprus' dynastic, political, and economic history. Most important here are the conflict between the regent Montbéliard and the crown and the failed attempt to bring Rhodes into the political orbit of the kingdom. ${ }^{42}$

To some extent, these three modern traditions simply reflect the source material that scholars have privileged, their disciplinary orientation, and their linguistic training. Although Choniates' Greek history of the Roman empire does mention Kaykhusraw, it centres Aldebrandinos and contextualizes the fate of Attaleia, by reference to the other provincial rulers, with whom he is listed in the History. ${ }^{43}$ While he is not constructed as important enough to be one of the heads of what Choniates terms the "three-headed monster constituted of the stupid", a critique reserved for Manuel Maurozomes, Theodore Laskaris, and David Komnenos, his appearance in the narrative is determined by events related to these other rulers. ${ }^{44}$ Kaykhusraw likewise dominates the Arabic account of Ibn al-Athìr, the Syriac account of Gregory Bar Hebraeus, and the Persian account of Ibn Bībì, but the prominence

38 Niketas Choniates, History, ed. van Dieten, 639, trans. Magoulias, 351.

39 Historiography concerning the later Seljuk conquest in 1216 is likewise centred on the person of 'Izz al-Din Kaykā'ùs (r. 1211-1220), while it is consistently made meaningful by reference to the succession struggle between Kaykā'ūs and his brother Alā' al-Dīn Kayqubād, precipitated by Kaykhusraw's death in 1211. For illustrative examples of the three traditions compare, descriptions by Byzantinists (Hoffmann, Rudimente von Territorialstaaten, 69-71, 100; Cheynet, Pouvoir et Contestations, 147-148) with those of historians of the Seljuk sultanate of Rum (Cahen, Pre-Ottoman Turkey, 119-120), and historians of crusader Cyprus (Edbury, Kingdom of Cyprus, 42-43; Hill, History of Cyprus, 74-75). Redford and Leiser (Victory Inscribed, 89-91) remains somewhat mixed, since the collaborative project included Byzantine specialists.

40 Hoffmann, Rudimente von Territorialstaaten; Brand, Byzantium Confronts the West; Cheynet, Pouvoir et Contestations.

41 Redford and Leiser, Victory Inscribed, esp. 89.

42 Edbury, Kingdom of Cyprus, 42-43.

43 Niketas Choniates, History, ed. van Dieten, 640, trans. Magoulias, 351.

44 Niketas Choniates, History, ed. van Dieten, 625-626, trans. Magoulias, 343. 
of Montbéliard is harder to justify on closer inspection of the source material, since he is not mentioned by name in any of the four histories. ${ }^{45}$ Indeed, since Ibn al-Athir states that all the Franks were killed and Bar Hebraeus that they were all captured, scholars are forced to hypothesise that Montbéliard was ransomed, although there is no direct evidence for this, in order to place him in Cyprus in late 1207, where his presence is attested. ${ }^{46}$

Despite their (relative) correspondence with the source material's privileging of these rulers, this mode of telling the story of the capture of Attaleia/Antalya/Satalia removes agency from the three group characters which appear even more consistently across all four narratives than these rulers, namely the Attaleians/Greeks, the Franks/Latins, and the Turks/ Persians/Muslims. ${ }^{47}$ The statist logic which singles out rulers and the stories of their states as the chief vectors of meaning obscures the agency of these core groups, which are subsumed into the agency of their leaders. For example, in both Bar Hebraeus and Ibn al-Athir's accounts, which offer very similar descriptions, the Greeks - who are also identified as ahl al-balad [the urban populace] - repeatedly act collectively in pivotal roles, sending for aid to the Franks of Cyprus, coming into conflict with them, and then sending for aid to the Muslims outside the city.

In short, modern historiographies have moulded the conquest of Attaleia/Antalya/Satalia into events that work for their own narratives. Although each tradition produces different events, dynamics, and meanings, they each produce these effects by recourse to the same logic of interpretation and construction. The first step towards breaking the stranglehold of this logic is to read for the agency of characters, like the Attaleians, who tend to be obscured by the narratives of states and rulers. The second is to produce more imaginative and less pre-determined frameworks of interpretation. Across the Anatolian, Caucasian, and Aegean world in this period, urban centres were involved in similar action, yet these happenings, as in this case study, have been produced as footnotes in statist narratives. The steady progression of Nicaea across western Anatolia, Trapezuntine conquests along the Black Sea coast in north-western Anatolia, Seljuq expansion throughout Anatolia, the conquests of crusaders across Greece, and Georgian expansion across Caucasia are all statist stories. Each of these stories, and many others, are predicated on lists of conquered urban centres, some described in more and others in less detail than the conquest of Attaleia/Antalya/Satalia. However, when examined differently, those same episodes produce alternative dynamics, logics, and agencies.

45 Ibn al-Athïr, Al-Kämil fĩ al-tārïkh, 12, ed. Tornberg, 252-253, trans. Richards, 123; Bar Hebraeus, Makhtbhanuth Zabhne, trans. Budge, 420-421. Edbury, Kingdom of Cyprus, 42-43. Hill, History of Cyprus, 74-75. Scott and Leiser, Victory Inscribed, 90.

46 Hill, History of Cyprus, $75, \mathrm{n} .1$.

47 The only exception is Ibn Bībī's narrative where the Franks and urban populace are collapsed into a single enemy. 


\section{Future Directions}

The extent to which the people of Attaleia/Antalya/Satalia or their narrative construction and function, in the four short passages briefly examined here, are representative or anomalous remains in question. Less well studied and/or attested examples not only abound but dominate. It will only be after extensive, collaborative, and accumulative work that a more macroscopic lens will be able to be applied to this problem. However, placing this tiny example under the microscope is intended to illuminate a potentially fruitful avenue of investigation, capable of fragmenting and denaturalising the state's role in traditional narration of the Anatolian, Caucasian, and Aegean past. The articles in this thematic section, while they offer a rich variety of other things as well, together both demonstrate the heuristic value of and lay the foundations for this potentially liberatory framework for approaching this period and space.

\section{Acknowledgement}

The present study was undertaken within the framework of the project »Moving Byzantium: Mobility, Microstructures and Personal Agency« (PI: Prof. Claudia Rapp; rapp.univie.ac.at) funded by the FWF Austrian Science Fund (Project Z 288 Wittgenstein-Preis). 


\section{References}

Asp, Annika, Trebizond and Constantinople, 1204-1453. Unpublished $\mathrm{PhD}$ thesis (University of Birmingham, 2019).

Bar Hebraeus, Makhtbhanuth Zabhne [Chronicon], trans. Ernest Alfred Thompson Wallis Budge, The Chronography of Gregory Abûl Faraj, the Son of Aaron, the Hebrew Physician, Commonly Known as Bar Hebraeus, 2 vols. (London, 1932).

Brand, Charles, Byzantium Confronts the West 1180-1204 (Cambridge MA, 1968).

Bryer, Anthony, Gibbon and the later Byzantine Empires, in: Rosamond McKitterick and Roland Quinault (eds), Edward Gibbon and Empire (Cambridge, 1997) 101-116.

Cahen, Claude, Pre-Ottoman Turkey (New York, 1968).

Cheynet, Jean-Claude, Pouvoir et Contestations à Byzance (963-1210) (Paris, 1990).

Dadoyan, Seta B., The Armenians in the Medieval Islamic World: Armenian Realpolitik in the Islamic World and Diverging Paradigmscase of Cilicia Eleventh to Fourteenth Centuries (New Brunswick, 2017).

De Nicola, Bruno, The Chobanids of Kastamonu: Politics, Patronage and Religion in 13th Century Anatolia (London, forthcoming 2022).

Eastmond, Anthony, Art and Identity in Thirteenth-Century Byzantium: Hagia Sophia and the Empire of Trebizond (Aldershot, 2004).

Eastmond, Antony, Tamta's World: The Life and Encounters of a Medieval Noblewoman from the Middle East to Mongolia (Cambridge, 2017).

Edbury, Peter, The Kingdom of Cyprus and the Crusades, 1191-1374 (Cambridge, 1991).

Gibbon, Edward, Decline and Fall of the Roman Empire, 12 vols (London, [1776-1789] 1906).

Giebfried, John, The Mongol invasions and the Aegean world (1241-61), Mediterranean Historical Review 28 (2013) 129-139.

Gramsci, Antonio, Prison Notebooks, translated from Italian by Joseph Buttigieg, 3 vols (New York, 2011).

Haldon, John (ed.), The Social History of Byzantium (Oxford, 2009).

Harvey, David, Spaces of Global Capitalism: A Theory of Uneven Geographical Development (London, 2005).

Hellenkemper, Hansgerd and Friedrich Hild, Lykien und Pamphylien, Tabula Imperii Byzantini 8 (Vienna, 2004).

Hill, George, A History of Cyprus: Volume 2: The Frankish Period, 1192-1432 (Cambridge, 2010 [1948]).

Hoffmann, J., Rudimente von Territorialstaaten im byzantinischen Reich, 1071-1210: Untersuchungen über Unabhängigkeitsbestrebungen und ihr Verhältnis zu Kaiser und Reich (Munich, 1974).

Ibn al-Athīr, Al-Kämil fĩ al-tārīkh, ed. Carolus Tornberg, Ibn-el-Athiri Chronicon Quod Perfectissimum Inscribitur, 14 vols (Leiden, 1851-1676). English translation: Donald Richards, The Chronicle of Ibn al-Athir for the Crusading Period, 3 vols (Aldershot, 2008).

Ibn Bībì, Al-Awāmir al-'alāìyyah, trans. Herbert Duda, Die Seltschukengeschichte des Ibn Bibi (Copenhagen, 1959).

Jackson, Peter, The Mongols and the West (1221-1410) (London, 2005).

Kaldellis, Anthony, Romanland: Ethnicity and Empire in Byzantium (Cambridge, MA, 2019).

Karpozilos, Apostolos, The Ecclesiastical Controversy between the Kingdom of Nicaea and the Principality of Epiros (1217-1233) (Thessalonike, 1973). 
Kinloch, Matthew, Rethinking Thirteenth-Century Byzantine Historiography: A Postmodern, Narrativist, and Narratological Approach. Unpublished DPhil thesis (University of Oxford, 2018).

Kinloch, Matthew, The Nikaian Narrative: Rethinking the historiography of the thirteenthcentury Byzantine world, in: Kutlu Akalin and Şahin Kiliç (eds), Iznik/Nicaea on its Way to Become a UNESCO World Heritage Site (Bursa, 2020) 471-490.

Korobeinikov, Dimitri, Byzantium and the Turks in the Thirteenth Century (Oxford, 2014).

Laclau, Ernest and Chantal Mouffe, Hegemony and Socialist Strategy (London, 2001).

Laiou, Angeliki (ed.), The Economic History of Byzantium: From the Seventh through the Fifteenth Century (Washington DC, 2002).

Laiou, Angeliki, Byzantium and the neighbouring powers: Small-state polities and complexities, in: Sarah Brooks (ed.), Byzantium: Faith and Power (1261-1557) (New Haven, 2006) 42-53.

Langdon, John, Byzantium's initial encounter with the Chinggisids: An introduction to the Byzantino-Mongolica, Viator 29 (1998) 95-140.

Lerner, Gerda, The Creation of Patriarchy (New York, 1986).

Lindner, Rudi Paul, Anatolia, 1300-1451, in: Kate Fleet (ed.), Cambridge History of Turkey: Byzantium to Turkey (1071-1453) 102-137.

Luttwak, Edward, The Grand Strategy of the Byzantine Empire (Cambridge MA, 2009).

Madgearu, Alexandru, The Asanids: The Political and Military History of the Second Bulgarian Empire (1185-1280) (Leiden, 2016).

May, Timothy, The Mongol presence and impact in the lands of the Eastern Mediterranean, in: Donald Kagay and L. J. Andrew Villalon (eds), Crusades, Condottieri, and Cannon: Medieval Warfare in Societies around the Mediterranean (Leiden, 2003) 133-156.

Melville, Charles, Anatolia under the Mongols, in: Kate Fleet (ed.), Cambridge History of Turkey: Byzantium to Turkey (1071-1453) 51-101.

Morgan, David, The Mongols and the Eastern Mediterranean, Mediterranean Historical Review 4 (1989) 198-211.

Niewöhner, Philipp (ed.), The Archaeology of Byzantine Anatolia: From the End of Late Antiquity Until the Coming of the Turks (Oxford, 2017).

Niewöhner, Philipp, Urbanism, in: Philipp Niewöhner (ed.), The Archaeology of Byzantine Anatolia: From the End of Late Antiquity until the Coming of the Turks (Oxford, 2017) 39-59.

Niketas Choniates, History, ed. Jan-Louis van Dieten, Nicetae Choniatae: Historia, Corpus Fontium Historiae Byzantinae 11 (Berlin, 1975). English translation: Harry Magoulias, O City of Byzantium, Annals of Niketas Choniates (Detroit, 1984).

Obolensky, Dimitri, The Byzantine Commonwealth: Eastern Europe, 500-1453 (London, 1974 [1971]).

Peacock, Andrew, Bruno De Nicola, and Nur Ylldız, Sara, Introduction, in: Andrew Peacock, Bruno De Nicola and Sara Nur Ylldız (eds), Islam and Christianity in Medieval Anatolia (Farnham, 2015) 1-20.

Peacock, Andrew and Sara Nur Ylldı (eds), The Seljuks of Anatolia: Court and Society in the Medieval Middle East (London, 2013).

Peacock, Andrew and Sara Nur Ylldız, Introduction, in: Andrew Peacock and Sara Nur Ylldız (eds), The Seljuks of Anatolia: Court and Society in the Medieval Middle East (London, 2013) 1-22.

Rapp, Stephen, Caucasia and the First Byzantine Commonwealth: Christianization in the Context of Regional Coherence (Seattle, 2012). 
Rapp, Stephen, Caucasia and the Second Byzantine Commonwealth: Byzantinization in the Context of Regional Coherence (Seattle, 2012).

Rayfield, Donald, Edge of Empires: A History of Georgia (London, 2013).

Redford, Scott, Landscape and the State in Medieval Anatolia: Seljuk Gardens and Pavilions of Alanya, Turkey (Oxford, 2000).

Redford, Scott, Legends of Authority: The 1215 Seljuk Inscriptions of Sinop Citadel, Turkey (Istanbul, 2014).

Redford, Scott and Gary Leiser, Victory Inscribed: The Seljuk Fetihname on the Citadel Walls of Antalya, Turkey/Taşa Yazılan Zafer: Antalya İçkale Surlarındaki Selçuklu Fetihnamesi (Istanbul, 2008).

Shepard, Jonathan (ed.), The Cambridge History of the Byzantine Empire (Cambridge, 2008).

Sipahi, Ali, Dzovinar Derderian and Yaşar Tolga Cora, Introduction: Ottoman historiography's black hole, in: Ali Sipahi, Dzovinar Derderian, and Yasar Tolga Cora (eds), The Ottoman East in the Nineteenth Century: Societies, Identities and Politics (London, 2016) 1-15.

Vryonis, Speros, The Decline of Medieval Hellenism in Asia Minor (Los Angeles, 1971). 